\title{
PRINSIP RESPONSIBILITY TO PROTECT (R2P) DALAM KONFLIK ISRAEL- PALESTINA: BAGAIMANA SIKAP INDONESIA?
}

\author{
Setyo Widagdo, Rika Kurniaty \\ Department Hukum Internasional, Fakultas Hukum-Universitas Brawijaya \\ Jl. Mayjend Haryono No. 169 Malang \\ Email: widagdo@ub.ac.id
}

\begin{abstract}
This article aims to discuss the Principles of Responsibility to Protect $(R 2 P)$ that may be applied to the conflict in the Gaza Strip between Israel and Palestine. This normative legal research using a conceptual approach and a case approach indicates that the humanitarian crisis resulting from the conflict needs to be the focus of the international community, and the $R 2 P$ principle may be applied as an alternative solution. Although the R2P principle is not a legal formulation, $R 2 P$ plays an important role. It is recognized as an emerging norm or an obligation with a legal significance. $R 2 P$ has been agreed upon and accepted by most countries globally that are members of the United Nations through UN General Assembly Resolutions. $R 2 P$ assigns responsibility to the international community to help parties protect populations from the crime of genocide. Ultimately, $R 2 P$ is expected to encourage states to fulfill their legal responsibilities and obligations, help build capacity to protect populations, and provide assistance to states in emergencies.
\end{abstract}

Key words: Responsibility to protect (R2P), Human Security, Human Rights, Israeli-Palestinian conflict

\begin{abstract}
Abstrak
Artikel ini bertujuan untuk mendiskusikan Prinsip Responsibility to Protect (R2P) yang mungkin diterapkan pada konflik di jalur Gaza antara Israel dan Palestine. Penelitian hukum normatif dengan pendekatan konsep dan pendekatan kasus ini menunjukkan bahwa krisis kemanusian yang terjadi akibat konflik tersebut perlu menjadi fokus masyarakat internasional, dan prinsip R2P perlu untuk diterapkan sebagai salah satu alternatif solusi. Meskipun prinsip R2P bukanlah suatu rumusan hukum, R2P berperan penting dan diakui sebagai sebagai emerging norm, atau suatu obligation with legal significance. R2P telah disepakati dan diterima oleh mayoritas negara-negara di dunia yang menjadi anggota PBB melalui Resolusi Majelis Umum PBB. R2P memberikan tanggung jawab kepada komunitas internasional untuk membantu para pihak melindungi penduduk dari kejahatan genocide. Pada akhirnya, R2P diharapkan dapat mendorong negara untuk memenuhi tanggung jawab dan kewajiban hukum mereka, membantu membangun kapasitas untuk melindungi penduduk, dan memberikan bantuan kepada negara dalam keadaan darurat.
\end{abstract}

Kata kunci: Responsibility to protect (R2P), Keamanan Manusia, Konflik Israel-Palestina 


\section{Latar Belakang}

Konflik di Gaza antara Israel-Palestina telah menghidupkan kembali perdebatan kompleks tentang penerapan Tanggung Jawab Melindung-Responsibility to Protect (selanjutnya akan disingkat "R2P" dalam tulisan ini). R2P sangat terkait dengan perlindungan terhadap jus cogens yang berperan besar dalam perlindungan keamanan seluruh masyarakat internasional. Dalam kondisi ketika suatu negara gagal melindungi HAM yang bersifat jus cogens, ${ }^{1}$ tanggung jawab untuk melindungi tersebut beralih ke masyarakat internasional yang lebih luas melalui konsep R2P. Tanggung jawab ini beralih ke masyarakat internasional dikarenakan HAM yang dilanggar ialah HAM yang bersifat khusus, meliputi: kejahatan genosida, kejahatan terhadap kemanusiaan, kejahatan perang, dan pembersihan etnis.

Konflik yang mengakibatkan hilangnya ratusan nyawa warga sipil Palestina, termasuk anak-anak dan perempuan tersebut menjadi isu yang belakangan ini banyak mencuri perhatian masyarakat Internasional. Diketahui setidaknya ada 200 korban jiwa yang meninggal, 1.300 orang terluka, dan sekitar 40.000 orang lainnya terpaksa mengungsi. ${ }^{2}$ Konflik tersebut bermula dari masalah domestik Israel di mana pada dua tahun terakhir terdapat empat kali pemilu legislatif ${ }^{3}$ yang menandakan adanya permasalahan domestik yang cukup rumit hingga memicu penyerangan dari Israel terhadap palestina. Banyak pendapat menyatakan bahwa isu Palestina dan Israel tidak hanya sekedar konflik melainkan penjajahan sehingga penyelesaiannya tidak bisa menggunakan resolusi konflik. Penerapan R2P menjadi pertimbangan karena pada konflik tersebut telah terjadi pembersihan etnis (Ethnic cleansing).

Majelis Umum PBB telah melakukan voting terkait pembahasan agenda sidang yakni laporan rutin dan tahunan, serta mengadopsi rancangan resolusi baru yang disampaikan oleh Sekretariat Jenderal PBB. Isi laporan yang dibahas adalah soal pencegahan genosida, kejahatan perang, pemusnahan etnis dan kejahatan terhadap kemanusiaan. Agenda rancangan resolusi itu membahas pembentukan mata agenda baru tahunan sidang Majelis Umum PBB tentang R2P. Kemudian sidang juga membahas permintaan Sekjen PBB untuk menyampaikan laporan tahunan tentang R2P di sidang umum. Hasil dari voting tersebut terdapat 115 negara menyatakan Yes $(\mathrm{Y}), 15$ negara menyatakan No (N) dan 28 negara menyakan Abstain (A). Indonesia termasuk yang menyatakan No, alias menolak. ${ }^{4}$ Sikap Indonesia di PBB ramai dibahas di media sosial. Indonesia

1 Secara sederhana, Jus Cogens dalam hukum internasional dapat diartikan sebagai asas atau norma yang tidak boleh dilanggar dalam keadaan apapun. Norma tersebut telah diakui dan dihormati oleh komunitas internasional.

2 Kompas.https://www.kompas.com/global/read/2021/05/21/065449870/kronologi-konflik-israel palestinaterkini-dari-masjid-al-aqsa-diserang? page=all. (Mei 2021). Diakses pada tanggal 1 Juni 2021

3 Pada umumnya Pemilu diadakan tiap 4 (empat) tahun sekali.

4 https://nasional.kompas.com/read/2021/05/21/08322721/pertemuan-majelis umum-pbb-menlu-retno-serukanpenghentian-kekerasan. (Mei 2021). Diakses pada tanggal 1 Juni 2021 
memberikan suara 'No' untuk resolusi militer, terhadap negara lain dengan tujuan 'responsibility to protect and the prevention of melindungi orang-orang yang berisiko di genocide, war crimes, ethnic cleansing, and dalamnya? Hal ini karena R2P merupakan crimes against humanity'.

Penolakan Indonesia terkait pemungutan suara di Majelis Umum PBB tersebut mendapat kritikan dan kecaman dari masyarakat, Indonesia dianggap tidak konsisten dengan sikap dan pernyataannya selama ini terhadap konflik Israel -Palestina. Namun, juru bicara Kementerian Luar Negeri menyatakan bahwa sikap 'No' yang dilakukan RI untuk resolusi PBB itu bukan berarti menentang isu atau konsep R2P. Indonesia menolak pembentukan mata agenda baru dengan pertimbangan tidak perlu membentuk mata agenda baru, karena selama ini pembahasan R2P di Majelis Umum PBB sudah berjalan dan penyusunan laporan Sekjen selalu dapat dilaksanakan. Posisi voting Indonesia adalah terkait hal-hal prosedural bukan terhadap gagasan R2P. Posisi Indonesia masih sama hingga kini, yaitu selalu aktif terlibat dalam pembahasan R2P semenjak 2005 hingga kini. Dengan demikian Indonesia tidak menolak gagasan mengenai rencana R2P. Indonesia akan terus aktif dalam pembahasan R2P, terlepas dari posisi voting Indonesia. ${ }^{5}$

Ada beberapa pertanyaan penting yang harus dipertimbangkan terkait dengan R2P dan konflik Israel-Palestina terkait waktu yang tepat bagi suatu negara untuk mengambil tindakan koersif, khususnya aksi konsensus masyarakat internasional mengenai norma internasional baru, yang pada akhirnya dapat menjadi aturan baru hukum kebiasaan internasional dengan kepentingan etis yang sangat mendasar dan kebaruan dalam sistem internasional. Evolusi dari wacana intervensi kemanusiaan, yang telah begitu memecah belah, ke arah konsep baru R2P telah menjadi bagian sejarah intelektual. Penerapan R2P dalam konflik Israel-Palestina, tidak mengalahkan kewajiban hukum yang sudah dimiliki para pihak, termasuk yang berada di bawah hukum humaniter internasional (IHL) dan hukum kebiasaan internasional. Penerapan R2P dapat memberikan kerangka kerja tambahan untuk memahami krisis, serta alat tambahan untuk advokasi oleh para pihak yang ingin memprioritaskan perlindungan sipil.

Artikel ini terbagi menjadi beberapa bagian pokok. Setelah bagian latar belakang ini, penulis akan menyajikan diskursus dan latar belakang R2P sebagai prinsip dalam hukum internasional. Bagian selanjutnya akan menyajikan penerapan R2P dalam konflik antara Israel- Palestina, dan bagaimana sikap pemerintah Indonesia. Bagian terakhir dalam artikel ini adalah penutup, berisi kesimpulan yang memuat rangkuman singkat untuk seluruh bagian.

5 https://www.antaranews.com/berita/2167890/prof-hikmahanto-jelaskan-no-vote-oleh-indonesia-terkait-r2p. (Mei 2021). Diakses pada tanggal 1 Juni 2021 


\section{Pembahasan}

\section{A. Prinsip Right to Protect dalam Masyarakat Internasional}

Responsibility to Protect (R2P)) adalah prinsip yang secara internasional sudah diterima dalam The Summit Outcome Document tahun 2005, khususnya Paragraf 138 dan 139, dan disahkan dalam Resolusi Majelis Umum PBB (MU PBB) No A/60/I tanggal 24 Oktober 2005. Prinsip ini ditegaskan kembali dalam Resolusi Dewan Keamanan PBB (DK PBB) No. S/RES/1674 tanggal 16 April 2006. Dalam Dokumen Hasil KTT Dunia PBB 2005 , kepala negara dan pemerintah membuat komitmen bersejarah untuk melindungi penduduknya dari genosida, kejahatan perang, kejahatan terhadap kemanusiaan, dan pembersihan etnis. R2P memiliki tiga pondasi penting, yaitu: ${ }^{6}$

1. Sebuah negara bertanggung jawab melindungi penduduknya dari genosida, kejahatan terhadap kemanusiaan, kejahatan perang, dan pembersihan etnis.

2. Masyarakat internasional bertanggun jawab membantu negara memenuhi tanggung jawab utamanya.

3. Apabila negara gagal melindungi warganya dari empat tindak kekerasan di atas dan gagal menegakkan perdamaian, masyarakat internasional bertanggung jawab untuk campur tangan lewat tindakan koersif seperti sanksi militer. Intervensi militer dianggap sebagai pilihan terakhir.
Selain tanggung jawab utama negara untuk mencegah kejahatan, R2P menempatkan kewajiban pada komunitas internasional untuk membantu negara dalam membangun kapasitas mereka untuk pencegahan terjadinya kejahatan. Jika suatu negara tidak mampu atau tidak mau melindungi penduduknya, atau pada kenyataannya melakukan kejahatan itu sendiri, masyarakat internasional memiliki tanggung jawab untuk mengambil tindakan yang tepat waktu dan tegas dengan menggunakan serangkaian tindakan non-koersif dan koersif, termasuk kekerasan (sebagai langkah terakhir). Meskipun tidak mengikat secara hukum, R2P didasarkan pada prinsip hukum dan kerangka normatifyang ada, dengan nilai tambah terletak pada pembingkaian ulang kedaulatan negara yang tidak hanya mencakup hak-hak negara tetapi juga kewajibannya untuk melindungi rakyatnya.

Dalam diskursus R2P, terdapat pertanyaan penting mengenai apakah R2P itu merupakan ketentuan hukum atau bukan? Penulis menilai R2P bukanlah suatu rumusan hukum, melainkan merupakan suatu konsep atau prinsip yang diakui dan dihormati oleh komunitas internasional. Sebagian ahli juga menyatakan R2P sebagai emerging norm, atau suatu obligation with legal significance. Terlepas dari apapun sebutannya, fakta mengunjukkan bahwa saat ini R2P telah disepakati dan diterima oleh mayoritas negaranegara di dunia yang menjadi anggota PBB

6 Badescu, Cristina G. Humanitarian intervention and the responsibility to protect: security and human rights (Google eBook). New York, NY: Taylor and Francis e-Library. 2010. hlm. 110. 
melalui Resolusi MU PBB. Hal ini setidaknya menunjukkan adanya komitmen politik negara-negara tersebut terhadap R2P.

Jika kita telaah lebih jauh, perkembangan prinsip R2P tidak terlepas dari situasi abad 20 yang dapat dikatakan sebagai "abad pembunuhan masal". Puluhan juta manusia di berbagai belahan dunia telah menjadi korban pembunuhan, penyiksaan maupun karena kelaparan akibat kejahatan-kejahatan yang dikenal sebagai pemusnahan masal (genocide), kejahatan perang (war crime), kejahatan terhadap kemanusiaan (crimes againts humanity) dan pembersiahan etnis (ethnic cleansing). ${ }^{7}$ Sejarah telah mencatat, selama Perang Dunia I, pembunuhan masal terhadap orang-orang Armenia memakan korban jiwa lebih dari satu juta orang. Pada Perang Dunia II, Rezim Nazi membunuh tidak kurang dari 11 (sebelas) juta orang termasuk 6 (enam) juta orang-orang Yahudi, dan tawanan perang.

Diketahui bahwa pada akhir Perang Dunia II masyarakat internasional telah menyatakan komitmennya bahwa mereka tidak akan pernah lagi mengulang kekejaman itu. Ketika PBB lahir tahun 1945, negaranegara anggota PBB menyatakan bahwa mereka dan masyarakat internasional tidak akan membiarkan pembunuhan masal dan kejahatan kemanusiaan yang lain terulang lagi. Namun komitmen negara-negara tersebut menghadapi tantangan yang serius, dimana dunia kembali dikejutkan oleh ulah pemimpin Khmer Merah, Polpot di Kamboja, yang telah melakukan pembunuham masal terhadap 2 (dua) juta orang rakyat Kamboja. Peristiwa tersebut kemudian dikenal sebagai "The Killing Field". Tidak hanya berhenti disini, peristiwa serupa terjadi lagi di Bosnia, Somalia, Rwanda, Congo dan Kosovo. Jutaan manusia, termasuk perempuan dan anakanak kembali menjadi korban kejahatan kemanusiaan. Peristiwa semacam ini juga berkali kali terjadi di Palestina sampai saat ini. Situasi ini membuktikan bahwa masyarakat internasional telah gagal mencegah kejahatan kemanusiaan.

Kegagalan komunitas Internasional tersebut disebabkan karena tidak adanya kesamaan persepsi antara negara-negara anggota PBB yang saling berbeda pendapat tentang boleh tidak tidaknya dilakukan intervensi. Di satu sisi terdapat kelompok negara yang tetap berpegang teguh pada prinsip tradisional tentang kedaulatan negara yang selalu dipahami bahwa kedaulatan adalah kekuasaan tertinggi yang dimiliki suatu negara dan tidak dapat diganggu gugat, serta selalu menghubungkan masalah kedaulatan negara ini dengan integritas wilayah, dimana negara memiliki kewenangan pengaturan hukum dalam yurisdiksi wilayahnya. Hal ini menghasilkan suatu pemahaman bahwa kedaulatan negara merupakan hak dari suatu negara atas independensi secara politik serta tidak mencampuri urusan dalam negeri negara lain.

7 Haines, Steven: Kassimeris, George, ed. “Chapter 18, Humanitarian Intervention: Genocide, Crimes Against Humanity and the Use of Force", The Ashgate research companion to modern warfare, Burlington, VT: Ashgate Publishing Ltd, pp.307-309. 2010 
Di sisi yang lain terdapat kelompok negara yang melihat adanya kebutuhan masyarakat internasional untuk melakukan intervensi jika kejahatan kemanusiaan terus terjadi. Kelompok kedua ini berpendapat bahwa kedaulatan negara bukan lagi sesuatu yang absolut. Keadaan inilah yang kemudian melahirkan prinsip R2P. Prinsip ini dilandasi suatu pemikiran bahwa kedaulatan negara harus didasarkan bukan pada hak dari setiap negara untuk melakukan apa yang dikehendakinya tanpa ada campur tangan internasional, melainkan kedaulatan negara harus didasarkan pada perlindungan terhadap rakyatnya yang wilayah tersebut. Dengan kata lain kedaulatan negara harus dibangun di atas konsep "kedaulatan sebagai tanggung jawab" (sovereignty as responsibilty). Negara tidak seharusnya mengambil keuntungan dari hak dan kewenangan yang terkandung dalam kedaulatannya, tetapi negara harus menerima tanggung jawab untuk melindungi rakyat yang tinggal dalam wilayahnya.

Gagasan tersebut lebih lanjut dikembangkan dan dikaji oleh International Comission on Intervention and State Sovereignty (ICISS), suatu lembaga internasional yang dibentuk oleh Pemerintah Kanada pada tahun 2000. Kemudian pada tahun 2001 ICISS menyampaikan laporannya tentang R2P, bahwa semua negara memiliki tanggung jawab utama untuk melindungi rakyat mereka dari pemusnahan masal, kejahatan perang, kejahatan terhadap kemanusiaan dan pembersihan etnis. Dalam laporannya ICISS juga menyatakan bahwa masyarakat internasional juga memiliki tanggung jawab untuk membantu negara melindungi rakyatnya dari empat kejahatan kemanusiaan tersebut. Jika suatu negara gagal memberikan perlindungan terhadapnya rakyatnya dari kejahatan kemanusiaan, maka masyarakat internasional harus mengambil tanggung jawab untuk melindungi rakyat dari negara tersebut. ${ }^{8}$ Dalam upaya perlindungan itu, masyarakat internasional juga harus menggunakan serangkaian cara diplomatik, ekonomi, hukum dan penggunaan kekuatan militer sebagai upaya terakhir dalam situasi yang sangat ekstrim dan mendesak. Laporan ICISS ini menandai perubahan tentang bagaimana masyarakat internasional harus merespon krisis kemanusiaan yang terjadi akibat konflik bersenjata.Bab.

\section{B. R2P dalam Konflik Israel- Palestina}

Diskusi tentang Konfli Israel-Paestina dan R2P berkaitan erat dengan hubungan norma dengan hukum humaniter internasional (International Humanitarian Law-IHL) atau hukum perang. Berakar pada perjanjian dan konvensi internasional, hukum humaniter internasional menetapkan kewajiban hukum kepada pihak-pihak dalam konflik bersenjata terlepas dari apakah konflik itu terjadi antar negara atau terjadi secara internal, dengan

8 Rahayu. Januari. "Eksistensi Prinsip 'Responsibility to Protect' dalam Hukum Internasional”. MMH Jilid 41 No. 1.2012 
pelanggaran hukum humaniter internasional yang merupakan kejahatan perang. Kewajiban tersebut antara lain untuk melindungi warga sipil, serta tawanan perang, yang terluka atau sakit, dan personel medis dan keagamaan. Selain perlindungan warga sipil, hukum humaniter internasional menetapkan kewajiban hukum untuk melindungi objek dan infrastruktur, termasuk rumah sakit, kekayaan budaya, dan ambulans. Kewajiban hukum tersebut mengartikulasikan ilegalitas menargetkan infrastruktur untuk kelangsungan hidup penduduk sipil. Sementara kejahatan kekejaman massal sering terjadi selama konflik, ada perbedaan yang jelas berkaitan dengan ruang lingkup dan penerapan hukum humaniter internasional dan R2P.

Sebagaimana dinyatakan sebelumnya, fokus R2P dibatasi hanya pada empat kejahatan dan pelanggaran dan kekejaman semacam itu dapat dilakukan di dalam dan di luar konflik. R2P memasukkan kejahatan perang sebagai salah satu dari empat kejahatan dan pelanggaran di mana negara berkewajiban untuk melindungi penduduknya. Kejahatan semacam itu dalam ruang lingkup norma terbatas pada kejahatan yang ditujukan terhadap penduduk sipil dan dilakukan secara luas dan sistematis. Dengan demikian, krisis akan muncul di mana hukum humaniter internasional dan R2P akan berlaku, tetapi akan ada juga krisis di mana R2P tidak akan relevan karena sifat konflik. Ini membawa kita pada pertanyaan tentang krisis IsraelPalestina saat ini di jalur Gaza.
Berdasarkan kajian yang tim penulis lakukan, sejalan dengan Kemetrian Luar Negeri RI< Majelis Umum PBB seharusnya tidak perlu menyusun agenda baru lagi untuk melaksanakan R2P. Pembahasan R2P oleh Sidang Majelis Umum PBB selalu dapat dilaksanakan dan sudah ada mata agendanya yaitu "Follow Up to Outcome of Millenium Summit". Selain itu konsep R2P juga sudah jelas tertulis di Resolusi 60/1 (2005 World Summit Outcome Document), paragraf 138 sampai 139. Oleh karena itu Majelis Umum PBB dan Dewan Keamana PBB harus segera merespon dengan cepat keinginan masyarakat internasional untuk melaksanakan R2P terhadap Palestina, sebelum korban manusia akibat kekejaman Israel bertambah parah.

Selanjutnya, setidaknya ada empat prinsip Hukum Perang yang patut menjadi diskusi masyarakat Internasional, yaitu terkait dengan hal-hal berikut ini:

a. Penargetan. Hukum Perang menegaskan bahwa jika ada keraguan mengenai karakteristik militer atau sipil dari target potensial, target tersebut harus dianggap sebagai sifat sipil. Dengan kata lain, jika ada keraguan tentang sifat militer dari target potensial, target tersebut tidak boleh diserang. Melakukan sebaliknya berarti melakukan kejahatan perang.

b. Prinsip kehati-hatian. Undang-undang mengharuskan kombatan mengambil langkah-langkah untuk meminimalkan kerugian yang dilakukan terhadap non-kombatan. Selain mengeluarkan 
peringatan sesekali, tidak sepenuhnya jelas tindakan apa yang telah diambil IDF untuk meminimalkan kerugian sipil. Misalnya, telah menargetkan fasilitas 'penggunaan ganda' tanpa terlebih dahulu memastikan bahwa warga sipil berada di luar bahaya. Kegagalan untuk menunjukkan kehati-hatian dalam praktik merupakan elemen dari perang tanpa pandang bulu dan berpotensi menjadi kejahatan perang.

c. Prinsip proporsionalitas. Di luar poin makro yang jelas tentang proporsionalitas operasi secara keseluruhan, ada pertanyaan penting apakah serangan individu sebanding dengan tujuan militer langsung mereka. Mengingat kurangnya kejelasan mengenai apa tujuannya, ini adalah penilaian yang sulit untuk dibuat, tetapi ada pertanyaan serius yang harus dijawab, apakah serangan spesifik yang mengakibatkan kematian warga sipil sebanding dengan tujuan militer mereka.

d. Penggunaan senjata yang secara inheren tidak pandang bulu di wilayah penduduk sipil. Israel dituduh menggunakan amunisi yang mengandung flechette logam di daerah berpenduduk sipil. Flechette dirancang untuk menyebabkan kehancuran pada kehidupan manusia di wilayah yang lebih luas daripada senjata konvensional. Ketika digunakan di daerah-daerah di mana warga sipil hadir, mereka dapat secara inheren tidak pandang bulu dan, oleh karena itu, penggunaannya di daerah-daerah tersebut dapat merupakan kejahatan perang.

PBB dan komunitas Internasional perlu dengan kritis memperhatikan bahwa tindakan kedua belah pihak (Israel dan Palestina) patut diselidiki secara menyeluruh dan tidak memihak. Mereka yang ditemukan bertanggung jawab atas kejahatan perang atau kejahatan terhadap kemanusiaan, dimintai pertanggungjawaban atas tindakannya. Mereka yang saat ini berbagi elemen kedaulatan atas Gaza dan sekitarnya juga berbagi tanggung jawab kedaulatan untuk melindungi penduduk di sana dari kejahatan kekejaman. Yaitu: Israel, Hamas, dan Otoritas Palestina memiliki tanggung jawab untuk mengambil tindakan positif untuk melindungi penduduk dari kejahatan kekejaman. Ini berarti bahwa, sementara Israel memiliki hak - dan tanggung jawab - untuk melindungi warganya dari kejahatan terhadap kemanusiaan, ia juga memiliki tanggung jawab untuk melakukan hal yang sama terhadap warga Palestina di Gaza. Demikian juga, Hamas memiliki tanggung jawab untuk melindungi mereka yang tinggal di wilayah yang dikuasainya. Namun jauh dari melindungi warga sipil Palestina, hal itu dengan sengaja membuat mereka menghadapi ancaman yang lebih besar.

Sejauh ini cara terbaik untuk memastikan bahwa warga sipil dilindungi dan tidak dirugikan oleh kejahatan kekejaman atau konsekuensi perang yang tidak diinginkan adalah gencatan senjata yang dilakukan secara singkat. Konflik bersenjata memberikan 
konteks di mana kejahatan kekejaman dilakukan dan warga sipil dirugikan. Semakin lama konflik berlangsung, semakin banyak warga sipil yang akan mati. Gencatan senjata akan mengakhiri pembunuhan langsung, diizinkan bantuan medis mengalir kepada mereka yang membutuhkan, memfasilitasi pembangunan kembali kehidupan dan bangunan yang hancur, dan menciptakan ruang untuk dialog politik serius yang sangat dibutuhkan. Mengingat bahwa para pihak sendiri telah terbukti tidak mampu dan tidak mau menyetujui gencatan senjata, terutama karena Hamas menolak gencatan senjata yang ditengahi oleh pemerintah Mesir, upaya internasional memiliki peran penting untuk dimainkan.

R2P memberikan tanggung jawab kepada komunitas internasional untuk membantu para pihak melindungi penduduk dari kejahatan genocide. Tanggung jawab ini memiliki tiga elemen utama: mendorong negara untuk memenuhi tanggung jawab dan kewajiban hukum mereka, membantu membangun kapasitas untuk melindungi penduduk, dan memberikan bantuan kepada negara dalam keadaan darurat. Dengan demikian, guna memahami penerapan R2P dalam krisis saat ini adalah pertanyaan tentang posisi Gaza sebagai entitas yang diduduki atau independen. Dalam hal ini, penting untuk mempertimbangkan argumen jika Gaza tidak dianggap sebagai wilayah pendudukan. Posisi ini berasal dari fakta bahwa, pada tahun 2005, Israel melakukan rencana pelepasan di mana, beberapa orang berpendapat, negara melepaskan pendudukannya atas Gaza. Wilayah itu kemudian direbut oleh Hamas, yang menyatakan otoritasnya sebagai entitas pemerintahan. Jika seseorang melihat Hamas sebagai otoritas pemerintahan, maka di bawah R2P, Hamas akan memiliki kewajiban untuk melindungi penduduknya di dalam perbatasannya dari pelaksanaan empat kejahatan dan pelanggaran, sebuah tanggung jawab yang juga akan ada bagi Israel sehubungan dengan populasinya. bertempat tinggal di wilayahnya.

Kewajiban-kewajiban tersebut di bawah hukum humaniter internasional dan kebiasan internasional akan menempatkan serangkaian pembatasan hukum atas tindakan semua pihak yang berkonflik dan mencakup perlindungan bagi penduduk dari kejahatan kekejaman, serta dari pelanggaran lainnya. Penerapan R2P akan sangat berbeda jika ditemukan bahwa Gaza adalah wilayah pendudukan di bawah otoritas Israel, pandangan yang dipegang oleh beberapa komunitas internasional, termasuk LSM, pemerintah dan aktor dan badan PBB.

Jika ditentukan bahwa R2P berlaku, maka sesuai dengan kewajiban yang diartikulasikan dalam Dokumen KTT Dunia 2005 dan laporan selanjutnya dari Sekretaris Jenderal Perserikatan Bangsa-Bangsa, masyarakat internasional dapat mengambil tindakan non-koersif dan koersif jika suatu negara tidak mampu atau tidak mau melindungi penduduknya, atau melakukan kejahatan terhadap rakyatnya. Langkah-langkah tersebut 
mencakup melakukan persuasi publik dan swasta, mendukung danmemfasilitasigencatan senjata kemanusiaan dan/atau resolusi krisis, membentuk Komisi Penyelidikan untuk menyelidiki situasi, menyediakan pengiriman layanan kemanusiaan, dan mengizinkan penggunaan kekuatan melalui Dewan Keamanan PBB. Setiap tindakan harus memprioritaskan kebutuhan perlindungan penduduk dan pelaksanaannya akan bervariasi berdasarkan kasus per-kasus, tergantung pada konteks situasi, serta berbagai masalah yang berdampak pada pengambilan keputusan politik. Masalah yang jelas adalah kemauan politik dari komunitas internasional untuk menerapkan langkah-langkah yang lebih kuat untuk melindungi warga sipil atau pencegahan kekejaman.

Elemen terakhir dari aspek R2P ini berkaitan dengan pengiriman bantuan kemanusiaan kepada masyarakat yang terkena dampak. Ada kebutuhan yang jelas dan mendesak untuk bantuan kemanusiaan, dan kebutuhan yang sama mendesaknya bahwa para pihak memberikan akses ke kemanusiaan dan mengambil langkah aktif untuk melindungi pekerja kemanusiaan dan yang mereka bantu. Dalam jangka panjang, bantuan harus melibatkan investasi yang lebih besar dalam pembangunan kembali infrastruktur Gaza yang hancur dan mengatasi hambatan untuk investasi baru. R2P dapat berkontribusi setidaknya dalam dua cara. Pertama, dengan membangun harapan bahwa Dewan Keamanan memiliki tanggung jawab perlindungan, dimana R2PmempersulitDewan untuk tidak melakukan apa pun jika situasinya memburuk. Kedua, seperti yang ditunjukkan oleh Resolusi 2165 tentang Suriah, R2P dapat menjadi bagian dari kesamaan antara anggota Dewan Keamanan ketika krisis perlindungan muncul. Jika krisis meningkat, R2P memberi jaminan perlindungan terhadap orang-orang yang rentan akan menjadi prioritas utama.

\section{Bagaimana Sikap Pemerintah Indonesia?}

Sebagaimana paparan diatas, banyak pihak yang memperdebatkan sikap Indonesia dalam sidang Majelis Umum PBB tentang Responsibility to Protect (R2P). Menteri Luar Negeri Republik Indonesia Retno LP Marsudi dalam Sidang Pleno ke-67 Sidang Majelis Umum PBB pada hari Jumat tanggal 21 Mei 2021 telah mengemukakan sejumlah langkah untuk mencapai solusi dari ketegangan Israel dan Palestina. Dalam Sidang Pleno yang berlangsung di Markas PBB, New York, Amerika Serikat tersebut, Menteri Luar Negeri RI mempertegas bahwa partisipasi pemerintah Indonesia dalam siding umum Majelis PBB adalah demi kemanusiaan dan demi keadilan masyarakat Palestina. Pemerintah Indonesia secara khusus meminta Majelis Umum PBB menghentikan kekerasan dan membentuk tim internasional di Yerusalem. Indonesia menekankan upaya negosiasi untuk mengakhiri pendudukan Israel di Palestina harus segera dilakukan, setelah gencatan senjata antara Israel dengan Hamas. Indonesia juga meminta PBB memastikan akses bantuan 
kemanusiaan ke Palestina, serta mendorong dimulainya negosiasi multilateral yang kredibel. ${ }^{9}$

Sejauh ini, posisi Indonesia dalam isu Palestina antara lain mendukung langkah Palestina mewujudkan kemerdekaan. Bagi Indonesia, isu Palestina dinilai menjadi isu sentral, khususnya di Timur Tengah. Indonesia endorong pengakuan kedaulatan Palestina oleh negara anggota PBB dan organisasi internasional. Mendukung inisiatif negaranegara \& PBB guna menghidupkan kembali perundingan damai dengan menggunakan solusi dua negara. Menggalang negaranegara Organisasi Kerja Sama Islam (OKI) menemukan solusi dalam penyelesaian masalah Palestina-Israel. Indonesia menyerukan persatuan di antara negaranegara untuk fokus memerdekakan Palestina melalui two state solution. Merespons ekalasi kekerasan yang terjadi di Palestina, khususnya Jalur Gaza dan Yerusalem, Pemerintah Indonesia melalui Kementerian Luar Negeri menyatakan, Indonesia secara konsisten mendukung pemenuhan hak warga Palestina. Indonesia telah menempuh jalur diplomasi untuk meredakan kekerasan yang telah terjadi.

Selain hal-hal tersebut, Indonesia juga mengambil langkah serius dengan mengeluarkan joint statement bersama Malaysia dan Brunei Darussalam mewakili ratusan juta penduduk muslim dunia. Pemerintah berpednapat bahawa walau konflik ini bukan tentang agama, tapi statement tersebut diharapkan dapat membantu Palestina melalui OKI, Gerakan Non-Blok, atau PBB.

\section{Penutup}

R2P merupakan alternatif intervensi kemanusiaan untuk menyelamatkan manusia darigenosida,pembersihanetnis, dankejahatan perang terhadap kemanusiaan. Dalam hal konflik intra-negara, di mana negara tidak mampu melindungi warganya dari kekejaman massal, masyarakat internasional mengambil alih tanggung jawabnya dengan upaya preventif dan bertanggung jawab dengan mengerahkan pasukan untuk mengurangi situasi konflik yang lebih buruk. Setelah itu, masyarakat internasional akan memberikan bantuan untuk pemulihan pascakonflik.

Indonesia diaharapkan konsisten mendukung penerapan R2P dan mendukung dilakukannya intervensi melalui pelaksanaan R2P guna mewujudkan komitmen politik dan moral berkaitan dengan tanggung jawab dan kewajiban setiap negara dan masyarakat internasional untuk memberikan perlindungan kepada setiap individu dari tindak kekejaman masal (mass atrocity). Memenuhi R2P berarti menghidupkan kembali pencarian penyelesaian konflik yang langgeng, yang mengakui kepentingan dan keprihatinan terhadap Israel dan Palestina. R2P berkontribusi karena membangun harapan bahwa Dewan Keamanan memiliki

9 https://nasional.kompas.com/read/2021/05/21/08322721/pertemuan-majelis umum-pbb-menlu-retno-serukanpenghentian-kekerasan. (Mei 2021). Diakses pada tanggal 1 Juni 2021 
tanggung jawab perlindungan, dan memaksa Dewan Keamanan memberi respon ketika krisis perlindungan muncul. R2P memberikan perlindungan terhadap mereka yang rentan akan menjadi prioritas utama dalam memberikan respon. $\mathrm{R} 2 \mathrm{P}$ penting untuk mengumpulkan sumber daya yang kita miliki untuk tujuan melindungi populasi dari kejahatan kekejaman yang mengejutkan hati nurani umat manusia terkait krisis IsraelPalestina, juga di situasi di mana kekejaman mengintai.

\section{DAFTAR PUSTAKA}

\section{Buku}

Bellamy, Alex. J. Responsibility to Protect: The

Global Effort to End Mass Atrocities,

Polity Press, Cambridge. 2009

J.L. Holzgrefe dan Robert O. Keohane. The

Humanitarian Intervention Debate, dalam Humanitarian Intervention:

Ethical, Legal and Political Dilemmas, Cambridge University Press, Cambridge. 2003

Setyo Widagdo, dkk. Hukum Internasional Dalam Dinamika Hubungan Internasional. Universitas Brawijaya Press, Malang. 2019

\section{Jurnal}

Anam, Muhammad. "Humanitarian Intervantion: The Principle of Responsibility to Protect (R2P).” Jurnal Hubungan Internasional. pp.1-11. 2015. Apetroe, Alexandru C. 2017. "The Responsibility to Protect. from “Emerging Norm” To a False Promise. A New Challenge to International Security Policy". Studia UBB. Europapea, LXII, hlm.71-110. 2017
Evans, Gareth, "From the Responsibility to Protect to Responsible Civilian Protection"DailyStar(28October2013). $<$ www.dailystar.com.1b/Opinion/ Commentary/2013/Oct-28/235969from-the-responsibility-to-protect-toresponsible-civilian-protectionoteash x\#axzz2wYxDMKEz>. Diakses pada tanggal 1 Juni 2021

Fitria. "Implementasi Doktrin Responsibility to Protect (Humanitarian Intervention) Dalam Hukum Internasional (Kasus Kosovo Libya Dan Suriah)". Lex Jurnalica. Vol 9, No.1. 2012.

Gallagher, A. The Responsibility to Protect Ten Years on from the World Summit: A Call to Manage Expectations, Global Responsibility to Protect, 7(3-4), 254-274. 2015.

Haines, Steven: Kassimeris, George, ed. "Humanitarian Intervention: Genocide, Crimes Against Humanity and the Use of Force", The Ashgate research companion to modern warfare, Burlington, VT: Ashgate Publishing Ltd, pp.307-309. 2010 
Hendra, Eric. "Sekuritisasi dalam Kerangka "R2P" dan Intervensi Kemanusiaan:

Dilema Antara Legalitas dan Legitimasi.” Jurnal Hubungan Internasional. pp. 131-14. 2015

Jennifer, M.W. Norm Robustness and the Responsibility to Protect, Journal of Global Security Studies, Volume 4, Issue 1.pp 53-72. 2019

Kurniaty, R. "The Right to Democracy Arrangement Under International Law”. RechtIdee. Issue No.2 vol.14. 2019

Nasution, H\& Nurangga, F. "Mekanisme Penerapan Intervensi Kemanusiaan dalam Hukum Nasional Indonesia." Jurnal Penelitian Hukum De Jure 20.2. hlm.189-204. 2020

Poerana, S.A dan Handayani, I. "Establishing The Status of Responsibility to Protect (R2P) As Customary International Law and Its Role in Preventing Mass Atrocities." Padjadjaran Journal of International Law, Volume 5, Number 1. 2021

Rahayu. Januari. "Eksistensi Prinsip 'Responsibility to Protect' dalam Hukum Internasional”. MMH Jilid 41 No. 1.2012

Sarkin, J, "Is the Responsibility to Protect An Accepted Norm in International Law in the post-Libya Era?", Groningen Journal of International Law, Vol. 1 No. 9, 2012.

\section{Surat Kabar}

"After Years of Quite, Israel-Palestinian Conflict Exploded. Why Now?". The New York Times. https://www.nytimes. com/2021/05/15/world/middleeast/ israel-palestinian-gaza-war.html. Diakses pada tanggal 1 Juni 2021

"Kecaman Indonesia Terhadap Israel Palestina yang Memanas. Kompas. https://www.kompas.com/global/ $\mathrm{read} / 2021 / 05 / 12 / 160923770 /$ kecaman-indonesia-terhadapkonflik-israel dan-palestina-yangmemanas?page=all”. (Mei 2021). Diakses pada tanggal 1 Juni 2021

"Kronologi Konflik Israel- Palestina Terkini: dari Masjid Al-Aqsa Diserang Sampai Genjatan Senjata”. Kompas.https://www.kompas.com/ global/read/2021/05/21/065449870/ kronologi-konflik-israel palestinaterkini-dari-masjid-al-aqsa-diserang? page=all. (Mei 2021). Diakses pada tanggal 1 Juni 2021

"Libya Security Forces Kill 84 Over Three Days", Human Rights Watch, http:// www.hrw.org/news/2011/02/18/libyasecurity-forces-kill-84-over-threedays. Februari 2011. Diakses pada tanggal 1 Juni 2021

"Pertemuan Majelis Umum PBB, Menlu Retno Serukan Penghentian Kekerasan Terhadap Warga Palestina”. Kompas. https://nasional.kompas.com/ 
$\mathrm{read} / 2021 / 05 / 21 / 08322721 /$ pertemuanmajelis umum-pbb-menlu-retnoserukan-penghentian-kekerasan. (Mei 2021). Diakses pada tanggal 1 Juni 2021

Prof Hikmahanto jelaskan "No Vote" oleh Indonesia terkait R2P. https://www. antaranews.com/berita/2167890/profhikmahanto-jelaskan-no-vote-olehindonesia-terkait-r2p. (Mei 2021). Diakses pada tanggal 1 Juni 2021

The Responsibility to Protect and the prevention of genocide, war crimes, ethnic cleansing and crimes against humanity. https://kemlu. go.id/newyork-un/en/news/13187/ the-responsibility-to-protect-and-theprevention-of-genocide-war-crimesethnic-cleansing-and-crimes-againsthumanity. (Mei 2021). Diakses pada tanggal 1 Juni 2021B

\section{Naskah Internet}

Human Rights Council Resolution 15/1, Situation of Human Rights in the Libyan Arab Jamhariya, 15th Spec.
Sess., U.N. Doc. A/HRC/RES/S-15/1. 2011

International Commission on Intervention and State Sovereignty (ICISS), The Responsibility to Protect: Report of the International Commission on Intervention and State Responsibility (2001). ICISS < http:// responsibilitytoprotect.org/ICISS $\% 20$ Report.pdf $>$ [ICISS]. Diakses pada tanggal 1 Juni 2021

International Commission on Intervention and State Sovereignty, "The Responsibility to Protect: Report of the International Commission on Intervention and State Sovereignty". December 2001

Responsibility to Protect: Timely and Decisive Response, U.N. Doc. A/66/874-S/2012/578. 2012

Security Council Resolution 1973, U.N. Doc. S/RES/1973. 2011

World Summit Outcome Document, supra note 27 at paras. 138-9; Implementing the Responsibility to Protect, Report of the Secretary-General, UN Doc. A/63/677. 2009 